\title{
PENGARUH ANGGARAN PENDIDIKAN, KUALITAS PENDIDIK DAN AKREDITASI SEKOLAH TERHADAP KUALITAS LULUSAN (STUDI KASUS SMA DI PROVINSI ACEH TAHUN 2017-2019)
}

\author{
Mahadi $^{1)}$ dan Win Konadi ${ }^{2 *}$ \\ 1, Magister Manajemen Fakultas Ekonomi Bisnis UNIKI \\ 2 Dosen Fakultas Ekonomi Universitas Almuslim \\ *email: winmanan1964@gmail.com
}

DOI:

https://doi.org/10.55178/idm.v1i2.200

ABSTRAK

Article history

Received:

September $1^{\text {st }}, 2020$

Revised:

September 10, 2020

Accepted:

September 25, 2020

Page:

$44-61$

Keywords:

Anggaran Pendidikan,

Kualitas Pendidik,

Tingkat Akreditasi

Sekolah,

Kualitas Lulusan
Tujuan penelitian untuk mengetahui bagaimana: 1) Pengaruh Anggaran Pendidikan terhadap Kualitas Lulusan, 2) Pengaruh Kualitas Pendidik terhadap Kualitas Lulusan, 3) Pengaruh Akreditasi Sekolah terhadap Kualitas Lulusan. Penelitian dengan ruang lingkup SMA setiap Kabupaten/Kota seProvinsi Aceh dengan kasus pengamatan tahun 2017-2019. Dengan subjek penelitiannya adalah Anggaran Pendidikan, Kualitas Pendidik, Tingkat Akreditasi Sekolah, dan Kualitas Lulusan SMA. Hasil penelitian, diperoleh hal-hal berikut: 1). Hasil pengujian ditemukan bahwa faktor Anggaran Pendidikan tidak berpengaruh terhadap Kualitas lulusan SMA di Provinsi Aceh. Sedangkan faktor Kualitas Pendidik (dengan indikator hasil UKG Guru), dan Tingkat Akreditasi Sekolah (dengan indikator perhitungan tingkat kualitas akreditasi setiap Kabupaten/kota di Provinsi Aceh) selama tahun 2017-2019, berpengaruh signifikans terhadap Kualitas Lulusan SMA di Provinsi Aceh. 2). Nilai korelasi secara simultan antara variabel Anggaran Pendidikan, Kualitas Pendidik, dan Tingkat Akreditasi, terhadap Kualitas lulusan adalah sebesar 0,507. Maka terdapat hubungan yang positif antara ketiga variabel yang diduga dalam penelitian terhadap variabel kualitas lulusan, dengan derajat sedang. Dan Nilai Determinasi adalah $R^{2}=0,258$ artinya kontribusi dari faktor Anggaran Pendidikan, Kualitas Pendidik, dan Tingkat Akreditasi, terhadap Kualitas lulusan adalah sebesar 25,8\%. Terdapat cukup besar faktor lainnya yakni 74,2\%.

\section{Pendahuluan (Introduction)}

Pakar legendaris dunia, Aristoteles, pernah berucap bahwa "Education is a function of the State, and is conducted, primarily at least, for the ends of the State. State - highest social institution which secures the highest goal or happiness of man. Education is preparation for some worthy activity. Education should be guided by legislation to make it correspond with the results of psychological analysis, and follow the gradual development of the bodily and mental faculties". Juga Imam Al-Ghazali menyatakan bahwa Pendidikan merupakan proses me-manusia-kan manusia sejak masa kejadiannya sampai akhir hayatnya melalui berbagai ilmu pengetahuan yang disampaikan dalam bentuk pengajaran secara bertahap, dimana proses pengajaran itu menjadi tanggung jawab orang tua dan masyarakat menuju pendekatan diri kepada Allah sehingga menjadi manusia sempurna.

Jadi pendidikan merupakan sebuah sarana untuk membangun martabat dan peradaban manusia sebagai seorang individu yang juga merupakan bagian dari suatu komunitas. Dengan pendidikan setiap individu berproses dan berpotensi menjadi manusia yang berkualitas baik secara mental, spiritual maupun kognitif. Kemajuan sektor pendidikan dari suatu bangsa akan menentukan kemajuan pada sektor-sektor lainnya. Oleh karena itu pendidikan harus berkualitas dan seiring dengan perkembangan zaman. Pendidikan berkualitas mengedepankan upaya untuk memberdayakan peserta didik untuk menggali kecerdasaan otak, kecerdasan hati, serta membekali keterampilan-keterampilan seperti yang dinyatakan dalam Undang-undang SISDIKNAS no. 20 tahun 2003. 
Dari bahasa manajemen dinyatakan bahwa pendidikan adalah modal dasar untuk menciptakan SDM yang unggul. Dunia pendidikan yang utama adalah sekolah. Sekolah merupakan salah satu lembaga alternatif pelayanan pendidikan. Sekolah sebagai suatu lembaga tentunya memiliki visi, misi, tujuan dan fungsi. Untuk mengemban misi, mewujudkan visi, mencapai tujuan, dan menjalankan fungsinya, sekolah memerlukan tenaga profesional, tata kerja organisasi dan sumber-sumber yang mendukung baik finansial maupun non finansial.

Namun, sampai saat ini pendidikan di Indonesia menjadi salah satu masalah yang sangat subtansial. Di era industri digital 4.0 saat ini, Indonesia seharusnya sudah mampu meningkatkan pendidikan, sehingga tidak kalah bersaing dengan negara lain. Namun kualitas pendidikan yang ditandai dengan mutu hidup orang Indonesia masih dibawah negara yang tidak diperhitungkan, seperti vietnam ataupun Thailan. Menurut data survei dari OECD (Organisation for Economic Co-operation and Development) yang merilis tentang sistem pendidikan terbaik dunia dan urutan negaranya menyatakan bahwa negara-negara yang memiliki kualitas pendidikan terbaik di bidang pendidikan matematika dan ilmu pendidikan alam (IPA) di dunia saat ini berturut-turut adalah Singapura, Hongkong, Korea Selatan, Jepang dan Taiwan. Sedangkan, negara Indonesia berada pada urutan ke 69 dari 76 negara yang disurvei di seluruh dunia.

Berdasarkan data The Learning Curve Pearson (2014), sebuah lembaga pemeringkatan pendidikan dunia, memaparkan jika Indonesia menduduki posisi akhir dalam mutu pendidikan di seluruh dunia. Indonesia menempati posisi ke-40 dengan indeks rangking dan nilai secara keseluruhan yakni minus 1,84 . Sementara pada kategori kemampuan kognitif indeks rangking 2014 versus 2012, Indonesia diberi nilai $-1,71$. Sedangkan untuk nilai pencapaian pendidikan yang dimiliki Indonesia, diberi skor $-2,11$. Posisi Indonesia ini menjadikan yang terburuk. Di mana Meksiko, Brasil, Argentina, Kolombia, dan Thailand, menjadi lima negara dengan rangking terbawah yang berada di atas Indonesia. Hal ini menunjukkan bahwa kualitas pendidikan kita masih rendah.

Upaya meningkatkan mutu pendidikan secara nasional merupakan salah satu program yang sedang dilaksanakan oleh pemerintah. Hal tersebut sebagaimana yang tercantum dalam Rencana Strategis Departemen Pendidikan Nasional. Upaya ini diarahkan agar setiap lembaga pendidikan selalu berupaya untuk memberikan jaminan mutu layanannya kepada pihak-pihak yang berkepentingan. Mutu layanan disini adalah jaminan bahwa proses penyelenggaraan pendidikan di sekolah sesuai dengan yang seharusnya terjadi dan sesuai pula dengan yang diharapkan. Apabila setiap satuan pendidikan selalu berupaya untuk memberi jaminan mutu secara terus menerus, maka diharapkan mutu pendidikan secara nasional akan terus meningkat.

Kualitas pendidikan sangat berhubungan dengan anggaran pendidikan, dan ini merupakan salah satu input yang sangat penting dalam meningkatkan pembangunan pendidikan. Tanpa dukungan dana yang cukup, akan sangat sulit mutu proses belajar mengajar dan mutu hasil belajar dapat dicapai. Biaya pendidikan diperlukan untuk memfasilitasi pelaksanaan kebijakan dan program sekolah, terlaksananya aktivitas sekolah (intra dan ekstra), dan dapat mengembangkan sekolah sebagai lembaga pendidikan yang bermutu. Dalam rangka meningkatkan mutu pendidikan melalui peningkatan mutu proses pembelajaran, pemerintah pusat maupun daerah terus meningkatkan biaya pendidikan.

Dalam artikel di kompas, 17 Mei 2016 (www.kompasiana.com/salsabila), dibahas tentang hal ini, Dan menyatakan Pendidikan adalah variabel yang menentukan kualitas sumber daya manusia suatu bangsa. Maka menjadi tanggung jawab pemerintah untuk dapat menjamin terselenggaranya pendidikan dengan mutu/kualitas yang baik. Berdasarkan UU Nomor 20 tahun 2003 tentang Sistem Pendidikan Nasional, diamanatkan bahwa pemerintah pusat dan pemerintah daerah wajib memberikan layanan dan kemudahan, serta menjamin terselenggaranya pendidikan yang bermutu bagi setiap warga negara tanpa diskriminasi. Untuk itu, didukung dengan anggaran yang tepat dan mencukupi.

Anggaran pendidikan adalah alokasi anggaran pada fungsi pendidikan yang dianggarkan melalui kementerian negara/lembaga. Alokasi anggaran pendidikan melalui transfer ke daerah, dan alokasi anggaran pendidikan melalui pengeluaran pembiayaan, termasuk gaji pendidik, namun tidak termasuk anggaran pendidikan kedinasan, untuk membiayai penyelenggaraan pendidikan yang menjadi tanggung jawab Pemerintah. Persentase anggaran pendidikan tersebut adalah perbandingan alokasi anggaran pendidikan terhadap total alokasi anggaran belanja negara. Berdasarkan data APBN tahun 2010 sampai dengan 2015 Alokasi anggaran pendidikan telah memenuhi amanat UUD 1945 yaitu minimal 20\% dari belanja negara. Alokasi anggaran pendidikan dilakukan tiga jalur. Pertama, Alokasi Anggaran Pendidikan melalui belanja Pemerintah Pusat meningkat dari Rp96,5 triliun pada tahun 2010 menjadi Rp154,2 triliun pada tahun 2015. Alokasi anggaran pendidikan pada Pemerintah Pusat digunakan antara lain untuk penyediaan beasiswa 
untuk siswa/mahasiswa kurang mampu, rehabilitasi ruang kelas, pembangunan unit sekolah baru dan ruang kelas baru, serta pembangunan prasarana pendukung dan pemberian tunjangan profesi guru. Kedua, alokasi anggaran pendidikan melalui transfer ke daerah antara lain terdiri dari bagian anggaran yang dialokasikan pada bagian anggaran. Ketiga, anggaran pendidikan melalui pengeluaran pembiayaan yang selanjutnya disebut dana pengembangan pendidikan nasional (DPPN), terdiri atas dana abadi (endowment funds) pendidikan dan dana cadangan pendidikan, dimana dana tersebut dikelola oleh BLU bidang pendidikan yaitu Lembaga Pengelola Dana Pendidikan (LPDP) yang merupakan satker dari Kementerian Keuangan. Dasar hukum Pengelolaan DPPN tersebut diatur dengan Peraturan Menteri Keuangan (PMK) Nomor: 238/PMK.05/2010 tentang Tata Cara Penyediaan, Pencairan, Pengelolaan dan Pertanggungjawaban Endowment Fund dan Dana Cadangan Pendidikan.

Menurut laporan Education Public Expenditure Review, yang dilansir World Bank, dan dipublikan dalam Republika (14-03-2013), dinyatakan "meskipun anggaran pendidikan Indonesia yang kini mencapai 20 persen dari APBN dan pembiayaan pendidikan yang terus meningkat beberapa tahun terakhir, ternyata belum membuahkan capaian pendidikan yang diharapkan". Skor Indonesia dalam sejumlah tes internasional menunjukan bahwa kualitas pendidikan di Indonesia masih sangat rendah dan belum menunjukkan perkembangan signifikan," kata Spesialis Pendidikan World Bank untuk Indonesia, Mae Chu Chang "bahwa rendahnya kualitas pendidikan meski anggaran pendidikan terus meningkat disebabkan belanja publik di sektor pendidikan hanya fokus pada jenjang pendidikan 9 tahun". Belanja publik di sektor pendidikan memang telah memperluas akses dan meningkatkan angka partisipasi sekolah selama satu dekade terakhir, terutama bagi kalangan siswa miskin. Kendati demikian, peningkatan angka partisipasi tersebut lebih terlihat pada tingkat wajib belajar 9 tahun yaitu jenjang Sekolah Dasar (SD) dan Sekolah Menengah Pertama (SMP). Sementara, akses terhadap level pendidikan menengah atas dan perguruan tinggi masih tergolong sangat rendah di kalangan siswa miskin".

Anggaran yang dibutuhkan untuk membayar gaji guru meningkat tajam seiring dengan meningkatnya jumlah guru secara keseluruhan dan jumlah ini terus meningkat. Meskipun program sertifikasi guru telah membantu memperbaiki kesejahteraan guru, namun belum terlihat adanya bukti bahwa program sertifikasi ini lantas diikuti dengan semakin membaiknya performa siswa.

Informasi lain, yang dirilis oleh situs indopos.co.id, (19 September 2018), menyatakan "Kementerian Pendidikan dan Kebudayaan (Kemdikbud) terus meningkatkan kualitas pendidikan nasional. Dengan anggaran yang tidak kecil, 60 persen anggaran ditransfer ke daerah. Anggaran Kementerian Pendidikan dan Kebudayaan tahun anggaran 2019 sebesar Rp.40,092 triliun. Dana tersebut dialokasikan untuk empat program besar. "Empat program itu meliputi peningkatan akses pendidikan, peningkatan kualitas pendidikan, peningkatan relevansi pendidikan dan peningkatan tatakelola dan akuntabilitas pendidikan," beber Sekjen Kementerian Pendidikan dan Kebudayaan.

Program peningkatan akses meliputi pembangunan unit sekolah baru dan ruang kelas baru. Pemberian Program Indonesia Pintar (PIP) dan beberapa program lainnya yang berkaitan dengan pemberian kesempatan belajar bagi anak Indonesia dimanapun mereka berada. Peningkatan mutu meliputi program peningkatan fasilitas sekolah mulai dari sarana pendidikan dan media pembelajaran. Perbaikan proses belajar mengajar, peningkatan profesionalisme guru dan kegiatan pengembangan kesiswaan. Sementara, untuk menyinkronkan program vokasi dengan dunia kerja, maka kerjasama antara sekolah dengan dunia usaha terus dilakukan. Mulai dari penyelarasan kurikulum, pengadaan peralatan praktek sekolah, perbaikan metodologi pembelajaran hingga evaluasi yang mengacu pada high orders thinking skills. Lalu, "Perbaikan tatakelola dan akuntabilitas melalui pelaksanaan program cashless untuk dana bos".

Sementara itu, Dirjen Guru dan Tenaga Kependidikan (GTK), Kementerian Pendidikan dan Kebudayaan, Supriano, menjelaskan, untuk meningkatkan mutu pendidikan nasional, pemerintah tengah menyusun program zonasi. Program berbasis wilayah tersebut bakal merumuskan kebijakan-kebijakan terkait pendidikan. Rencananya peningkatan kualitas proses pembelajaran dalam kelas ini, melalui Musyawarah Guru Mata Pelajaran (MGMP) dan kelompok kerja bersama (KKB) untuk tingkat SD. Hal ini akan memetakan setiap masalah yang dihadapi pendidikan nasional. Jadi MGMP akan fokus pada zonasinya masing-masing, apakah itu sekolah negeri maupun swasta. MGMP bisa saja mengajak bagaimana mengajarkan mata pelajaran matematika yang menyenangkan. Proses pembelajaran ini tentu menekankan bagaimana anak bisa berfikir kritis, komunikatif dan inovatif. Sebelumnya, pemerintah telah melakukan program peningkatan kompetensi guru. Namun saat ini, program tersebut hanya diberlakukan di beberapa saja, seperti di antaranya di wilayah terluar, terdepan dan tertinggal (3T). 
Berkaitan dengan keterangan yang terjadi di Indonesia, tentang kebijakan yang dilakukan dengan penyediaan anggaran kaitannya dengan peningkatan mutu pendidikan, maka hal yang ada di Provinsi Aceh, yang merupakan salah satu daerah yang mendapatkan dana otonomi khusus (otsus) dari pemerintah pusat. Setiap 5 tahunnya dana yang dianggarkan untuk bidang pendidikan mencapai rata-rata $R p$ 2,4 trilyun. Dana tersebut berasal dari dana otonomi khusus, dana bagi hasil migas dan dari sumber lain. Dana otsus yang diterima oleh Pemerintah Aceh, akan dibagikan kepada setiap daerah.

Selain masalah anggaran pendidikan, kualitas pendidik juga sangat dibutuhkan dalam hal meningkatkan kualitas pendidikan. Hal ini ditunjukkan dengan peningkatan kompetensi guru, seperti kompetensi profesional, kompetensi pedagogik guru dalam memasuki era globalisasi dan industri 4.0 ke depan. Berbicara masalah rendahnya pendidikan di Indonesia maka tak lepas dari peningkatan kompetensi dan profesionalitas guru. Guru adalah unsur yang paling penting dalam proses pendidikan. Tanpa adanya guru, pendidikan hanya menjadi slogan dan pencitraan karena segala bentuk kebijakan dalam sektor pendidikan pada akhirnya yang menentukan tercapainya tujuan pendidikan adalah guru. Guru menjadi titik sentral dan awal dari semua pembangunan pendidikan. Peranan guru sangat menentukan dalam usaha peningkatan mutu kualitas pendidikan bangsa. Untuk itu guru sebagai komponen kunci dalam pendidikan dituntut untuk mampu menyelenggarakan proses pembelajaran dengan sebaik-baiknya, untuk mewujudkan kejayaan pembangunan bangsa. Untuk dapat melaksakan fungsi guru dengan baik, maka guru perlu meningkatkan mutu dan kualitasnya. Peningkatan mutu dan kualitas guru ini diperlukan untuk memberikan proses pembelajaran yang berkualitas sehingga peserta didik terbentuk karakter yang kuat dan cerdas.

Dalam artikel Rohmah pada Kompasiana, 29 Juli 2015, diungkapkan bahwa: “Ada beberapa tahapan yang bisa dilakukan untuk meningkatkan kualitas guru. Pertama, merekrut calon guru pendidikan dengan cara merekrut lulusan sarjana terbaik dari prestasi maupun akademiknya dari berbagai provinsi di Indonesia. Dengan memiliki guru yang berprestasi dan memiliki kualitas yang baik. Dan akan berpengaruh besar terhadap kaulitas peserta didik. Hal ini karena ada hubungan antara prestasi kualitas guru dengan prestasi belajar peserta didik. Kedua, memberikan pendidikan pembentukan karakter dan memperbanyak latihan mengajar kepada calon guru yang materinya bisa berisi tentang mengenal diri sendiri, manajemen waktu, menetapkan target, bersikap proaktif, menghargai perbedaan, tenggang rasa, metode pembelajaran yang efektif, pengenalan sekolah, latihan mengajar dan lain sebagainya. Ketiga, memberikan jenjang karir yang jelas dan memberikan kesejahteraan yang sesuai. Hal ini diberikan untuk meningkatkan motivasi kerja bagi guru agar memberikan pelayanan pembelajaran yang berkualitas terhadap peserta didik. Keempat, peningkatan mutu guru dengan mengadakan pelatihan mengajar berlandaskan IPTEK dalam periode tertentu. Hal ini bertujuan untuk memberikan pembekalan terhadap guru agar mampu memberikan proses pembelajaran yang kreatif dan menyenangkan berdasarkan IPTEK. Kelima, menjaring guru yang berkompeten yang sesuai dengan kebutuhan dan disalurkan ke daerah-daerah terpencil yang mengalami kekurangan dalam aksesbilitas pendidikan. Keenam, mengadakan dan mengaktifkan organisasi profesi guru, dimana tiap daerah harus ada kegiatan dari organisasi profesi guru. Tujuannya yaitu sebagai wadah diskusi dan informasi seputar pendidikan yang dapat memberikan sumbangsih dalam proses pembelajaran. Iklim organisasi mampu mengajarkan semangat membangun dan melatih soft skill dari guru. Dan Ketujuh, memonitoring guru setiap awal pembelajaran baru. Dalam hal ini guru harus mempersiapkan pembelajaran yang akan diajarkan dalam periode awal beserta metode dan hasil yang akan di capai.

Persoalan mutu lulusan telah menjadi salah satu isu sentral yang selalu hangat dan menarik didiskusikan oleh berbagai kalangan saat ini, mulai dari kaum intelektual, praktisi pendidikan, guru, elite politik, budayawan, sampai kepada masyarakat awam. Akhirnya, mereka sampai pada kesimpulan, bahwa mutu lulusan nasional belum mampu diangkakan secara signifikan sehingga memuaskan semua pihak terutama pemakai hasil pendidikan. Persoalan mengenai kualitas lulusan bukanlah sesuatu yang mudah, tetapi hal tersebut merupakan sebuah proses yang kompleks dan memerlukan pemikiran yang mendalam dari semua pihak yang berkompeten. Permasalahan mutu lulusan pada saat ini lebih bertumpu pada masalah kualitas lulusan yang dihasilkan oleh sekolah itu sendiri, di mana kita harus mengakuinya.

Mutu lulusan merupakan pilar untuk menghasilkan sumber daya manusia yang baik dan handal, sehingga dengan demikian usaha-usaha peningkatannya harus selalu dilakukan secara terus menurus. Tetapi pada kenyataannya, usaha-usaha tersebut masih belum maksimal dan memuaskan. Salah satu faktor penyebabnya pencapaian mutu lulusan adalah kinerja kepala sekolah. Mutu kinerja kepala sekolah dapat diukur dari produktifitas kerja, sedangkan produktifitas kerja dipengaruhi oleh faktor-faktor seperti pandidikan, keterampilan, disiplin, motivitas, sikap, dan etika kerja, gizi dan kesehatan, jaminan sosial, tingkat penghasilan, iklim, dan lingkungan kerja, teknologi, sarana produksi, manajemen dan kesempatan berprestasi. 
Menurut Testriono (2005) ada tiga masalah utama dalam pendidikan nasional, yaitu sarana pendidikan yang tidak memadai dan belum dapat dinikmati oleh semua warga masyarakat, SDM pendidik (guru/dosen) yang kualitasnya belum memadai, dan kurikulum yang belum memperlihatkan arah yang jelas dan orientasi ke depan yang prospektif. Untuk menilai penyelenggaraan pendidikan, pemerintah memberikan peringkat pengakuan pada sekolah didasarkan hasil akreditasi yang dilaksanakan oleh Badan Akreditasi Nasional (BAN). Akreditasi dalam dunia pendidikan adalah pengakuan atas suatu lembaga pendidikan yang menjamin standar minimal sehingga lulusannya memenuhi kualifikasi untuk melanjutkan pendidikan ke tingkat yang lebih tinggi atau memasuki pendidikan spesialisasi, atau untuk dapat menjalankan praktek profesinya.

Hasil Ujian Nasional merupakan output nilai yang diperoleh siswa sebagai perwujudan kemampuan akademik dari sebuah proses pembelajaran. Berdasarkan data yang dirilis oleh Puspendik pada Bulan September 2019, diperoleh data bahwa nilai rata-rata UN SMA IPA di Provinsi Aceh adalah 43,11 dan Nasional adalah 53,00. Selanjutnya, rata-rata UN SMA IPS Tahun 2019 adalah 39,22, sdangkan Nasional 47,42. Tetapi setiap tahun adanya kecenderungan peningkatan. Kementerian Pendidikan dan Kebudayaan (Kemendikbud) RI menyatakan hasil Ujian Nasional SMA tahun 2019 berada peringkat ke-27, Aceh berada satu tingkat di atas Papua dan masih di bawah Gorontalo dan Sulawesi Selatan di posisi 25 dan 26.

Menyikapi permasalahan di atas, diperlukan pendidikan yang dapat menghasilkan sumber daya manusia berkemauan dan berkemampuan untuk senantiasa meningkatkan kualitas secara terus menerus dan berkesinambungan. Untuk merealisasikan tujuan tersebut, pemerintah menetapkan empat strategi pokok pembangunan pendidikan. Yaitu, relevansi pendidikan dengan pembangunan, kualitas pendidikan, dan efesiensi pengolahan pendidikan. Strategi tersebut jika dilaksanakan secara proporsional dan profesional, maka diyakini dapat menyelesaikan permasalahan pendidikan selama ini. Namun pada kenyataannya tidak demikian, karena pelaksanaan strategi tersebut seringkali tidak dilakukan oleh ahlinya, sehingga tidak pernah menyelesaikan permasalahan yang sesungguhnya.

Mutu pendidikan adalah tolak ukur keberhasilan sebuah proses pendidikan yang bisa dirasakan oleh masyarakat mulai dari input (masukan), proses pendidikan yang terjadi, hingga output (produk keluaran) dari sebuah proses pendidikan (Amri, 2013:6). Sedangkan Menurut Achmad dalam Amri (2013:6) menyebutkan "Mutu pendidikan adalah kemampuan sekolah dalam pengelolaan secara oprasional dan efisien terhadap komponen-komponen yang berkaitan dengan sekolah, sehingga menghasilkan nilai tambah terhadap komponen tersebut menurut norma/standar yang berlaku”.

Jadi dapat disimpulkan bahwa mutu pendidikan adalah tolak ukur keberhasilan sebuah proses pendidikan sehingga menghasilkan nilai atau standar yang berlaku. Peran kinerja guru sangat menunjang jalannya suatu proses pendidikan yang secara tidak langsung dengan lancarnya atau terselenggaranya program sekolah dengan baik danakan mampu meningkatkan mutu pendidikan yang terdiri dari standar kompetensi lulusan, standar proses, standar pendidik, dan standar pengelolaan. Dengan kinerja guru ini diharapkan mampu meningkatkan semangat dan motivasi belajar siswa hingga nantinya mampu meningkatkan prestasi belajar siswa dan mutu pendidikan.

Berdasarkan latar belakang di atas, maka peneliti tertarik untuk melakukan sebuah penelitian tentang "Pengaruh Anggaran Pendidikan, Kualitas Pendidik dan Akreditasi Sekolah terhadap Kualitas Lulusan pada SMA di Provinsi Aceh".

\section{Tinjauan Literatur (Literature Review)}

\section{a. Anggaran Pendidikan}

Dalam Undang-Undang Sistem Pendidikan Nasional Nomor 20 tahun 2003 pasal 46 ayat (1) menyatakan bahwa pembiayaan pendidikan merupakan hubungan saling keterkaitan yang di dalamnya terdapat komponen-komponen yang bersifat mikro dan makro pada satuan pendidikan yang bertujuan pada peningkatan potensi SDM yang berkualitas, penyediaan komponen-komponen sumber-sumber pembiayaan pendidikan, penetapan sistem dan mekanisme pengalokasian dana, pengefektifan dan pengefisiensian penggunaan dana, akuntabilitas (dapat dipertanggungjawabkan) dari aspek keberhasilan dan mudah terukur pada setiap satuan pendidikan, dan meminimalisir terjadinya permasalahan-permasalahan yang terkait dengan penggunaan pembiayaan pendidikan (Ferdi, 2013:566).

Sementara menurut Bray mengungkapkan bahwa pembiayaan pendidikan menyangkut sumber-sumber biaya baik dari pemerintah maupun dari masyarakat, dan alokasi belanja untuk proses pengajaran, termasuk pengeluaran sekolah untuk gaji dan berbagai pelayanan di setiap jenis sekolah. (Nurochim, 2016:255). 
Dengan kata lain, pembiayaan pendidikan menyangkut sumber-sumber dan alokasi dana untuk penyelenggaraan pendidikan. Pengertian lain dari pembiayaan pendidikan adalah sebagaimana yang diutarakan Nanang Fattah bahwa pembiayaan pendidikan merupakan jumlah uang yang dihasilkan dan dibelanjakan untuk berbagai keperluan penyelenggaraan pendidikan yang mencakup gaji guru, peningkatan profesional guru, pengadaan sarana ruang belajar, perbaikan ruang, pengadaan peralatan, pengadaan alatalat dan buku pelajaran, alat tulis kantor (ATK), kegiatan ekstrakurikuler, kegiatan pengelolaan pendidikan, dan supervisi pendidikan. (Mulyono, 2010:78).

Pembiayaan pendidikan merupakan salah satu komponen masukan yang sangat penting dalam penyelenggaraan pendidikan (khususnya di sekolah). Dalam setiap upaya pencapaian tujuan pendidikan, biaya pendidikan mempunyai peranan yang sangat menentukan. Hampir tidak ada upaya yang mengabaikan peranan biaya, sehingga dapat dikatakan bahwa tanpa biaya, proses pendidikan tidak berjalan, maka dapat disimpulkan bahwa pembiayaan pendidikan adalah suatu analisa tentang sumber-sumber dan penggunaan biaya yang diperuntukkan bagi pengelolaan pendidikan secara efisien guna mencapai tujuan.

Anggaran pendidikan melalui belanja pemerintah pusat merupakan alokasi anggaran pendidikan yang dianggarkan melalui kementrian Negara/lembaga. Kementrian Negara yang mendapat alokasi anggaran pendidikan bukan hanya kementrian pendidikan dan kebudayaan serta kementrian agama tetapi juga kementrian/lembaga lain yang menyelenggarakan fungsi pendidikan. Tujuan anggaran pendidikan antara lain: 1) Menjamin keberlangsungan pendidikan bagi generasi berikutnya, sebagai bentuk pertanggung jawaban antar generasi (intergenerational equity) yang pengelolaannya menggunakan mekanisme dana bergulir. 2) Dana cadangan pendidikan digunakan untuk mengantisipasi keperluan rehabilitasi fasilitas pendidikan yang rusak akibat bencana alam dan dilakukan oleh badan layanan umum (BLU) pengelola dana bidang pendidikan.

Peraturan Pemerintah Nomor 48 Tahun 2008 Pasal 3 Ayat 1, menjelaskan jenis-jenis biaya pendidikan meliputi:

1) Biaya satuan pendidikan, di antaranya: (a) Biaya investasi, yang terdiri atas biaya investasi lahan pendidikan dan biaya investasi selain lahan pendidikan; (b) Biaya operasi, yang terdiri atas biaya personalia dan biaya nonpersonalia; (c) Bantuan biaya pendidikan; dan (4) Beasiswa (PP No. 40 Tahun 2008 Pasal 3 Ayat 2).

2) Biaya penyelenggaraan dana atau pengelolaan pendidikan, meliputi: (a) Biaya investasi, yang terdiri atas biaya investasi lahan pendidikan dan biaya investasi selain lahan pendidikan; (b) Biaya operasi, yang terdiri atas biaya personalia dan nonpersonalia (PP No. 40 Tahun 2008 Pasal 3 Ayat 3).

3) Biaya pribadi peserta didik, meliputi: (a) Biaya personalia satuan pendidikan, yang terdiri atas gaji pokok bagi pegawai pada satuan pendidikan, tunjangan yang melekat pada gaji bagi pegawai pada satuan pendidikan, tunjangan struktural bagi pejabat structural pada satuan pendidikan, tunjangan fungsional bagi pejabat fungsional di luar guru dan dosen, tunjangan fungsional atau subsidi tunjangan fungsional bagi guru dan dosen, tunjangan profesi bagi guru dan dosen, tunjangan khusus bagi guru dan dosen, maslahat tambahan bagi guru dan dosen, dan tunjangan kehormatan bagi dosen yang memiliki jabatan profesor atau guru besar; (b) Biaya personalia penyelenggaraan dan atau pengelolaan pendidikan, yang terdiri atas gaji pokok, tunjangan yang melekat pada gaji, tunjangan struktural bagi pejabat struktural, dan tunjangan fungsional bagi pejabat fungsional (PP No. 40 Tahun 2008 Pasal 3 Ayat 4).

\section{b. Kualitas Pendidikan}

Kualitas pendidikan merupakan salah satu tolak ukur yang menentukan martabat atau kemajuan suatu bangsa. Mencermati mutu pendidikan suatu bangsa atau negara, seseorang dapat memperkirakan peringkat negara tersebut di antara negara-negara di dunia. Oleh karena itu, bangsa yang maju akan selalu menaruh perhatian besar terhadap dunia pendidikannya dengan melakukan berbagai upaya untuk meningkatkan mutu pendidikan, seperti meningkatkan anggaran pendidikan, menyelenggarakan berbagai lomba dalam berbagai aspek pendidikan, atau mengirimkan para tunas bangsa untuk menimba ilmu di negara lain. Beragam upaya ini dilakukan karena kesadaran, pentingnya pendidikan dan keyakinan bahwa bangsa yang mengabaikan pendidikan, menjadi bangsa yang tertinggal yang akan kalah bersaing dengan bangsa-bangsa lain.

Mutu di bidang pendidikan meliputi mutu input, proses, output, dan outcome. Input pendidikan dinyatakan bermutu jika siap berproses. Proses pendidikan bermutu apabila mampu menciptakan suasana yang PAKEM. Pendidkan yang bermutu adalah pendidikan yang mampu menghasilkan lulusan yang memiliki kemampuan atau kompetensi, baik kompetensi akademik maupun kompetensi kejuruan, yang dilandasi oleh 
kompetensi personal dan sosial, serta nilai-nilai akhlak mulia, yang keseluruhannya merupakan kecakapan hidup (life skill). Lebih lanjut Sudrajad mengemukakan pendidikan bermutu adalah pendidikan yang mampu menghasilkan manusia seutuhnya (manusia paripurna) atau manusia dengan pribadi yang integral (integrated personality) yaitu mereka yang mampu mengintegralkan iman, ilmu, dan amal.

Diungkapkan oleh Stanley J. Spanbauer (1992) dalam Uhar Suharsaputra, (2010:231), "Quality improvement in education should not be viewed as a "quick fix process". It is a long term effort which require organizational change and restructuring". Ini berarti bahwa banyak aspek yang berkaitan dengan kualitas pendidikan, dan suatu pandangan komprehensif mengenai kualitas pendidikan merupakan hal yang penting dalam memetakan kondisi pendidikan secara utuh, meskipun dalam tataran praktis, titik tekan dalam melihat kualitas bisa berbeda-beda sesuai dengan maksud dan tujuan suatu kajian atau tinjauan.

L.C. Solmon dalam tulisannya yang berjudul The Quality of Education menyatakan bahwa untuk memahami kualitas pendidikan dari sudut pandang ekonomi diperlukan pertimbangan tentang bagaimana kualitas itu diukur. Dalam hubungan ini terdapat beberapa sudut pandang dalam mengukur kualitas pendidikan, yaitu: 1) Pandangan yang menggunakan pengukuran pada hasil pendidikan (sekolah atau college). 2) Pandangan yang melihat pada proses pendidikan. 3) Pendekatan teori ekonomi yang menekankan pada akibat positif pada siswa atau pada penerima manfaat pendidikan lainnya yang diberikan oleh institusi dan atau program pendidikan. (Uhar Suharsaputra, 2010:231).

Adapun jika dilihat dari sudut pandang korelasi mutu dengan pendidikan, mutu dapat diartikan, sebagaimana pengertian yang dikemukakan oleh Dzaujak Ahmad bahwa mutu pendidikan adalah kemampuan sekolah dalam pengelolaan secara operasional dan efisien terhadap komponen-komponen yang berkaitan dengan sekolah sehingga menghasilkan nilai tambah terhadap komponen tersebut menurut norma/standar yang berlaku. (Sri Minarti, 2011:328).

Kualitas pendidikan bersifat dinamis, yang artinya dapat ditelaah dari berbagai sudut pandang. Pengertian kualitas pendidikan biasanya diukur dari sisi pelanggannya baik pelanggan internal (seperti kepala sekolah, guru, dan staf pendidikan) atau pelanggan eksternal (yaitu peserta didik, orang tua, masyarakat, dan pemerintah). Selain itu, kualitas dalam konteks pendidikan menurut penulis mengacu pada hasil atau prestasi yang dicapai oleh sekolah pada setiap kurun waktu tertentu, maka dapat disimpulkan kualitas pendidikan merupakan kemampuan system pendidikan baik dari segi pengelolaan maupun dari segi proses pendidikan, yang diarahkan secara efektif untuk meningkatkan nilai tambah dan faktor-faktor input agar menghasilkan output yang

\section{c. Kualitas Pendidik}

Tugas dan tanggung jawab seorang guru sangat erat kaitannya dengan kemampuan guru dalam usaha meningkatkan proses pengelolaan pembelajaran dan hasil belajar. Seorang guru harus mempunyai kecakapan dalam mengelola proses belajar mengajar sehingga dalam proses pengelolaan pembelajaran tersebut guru berkemampuan dalam menciptakan suasana komunikasi yang edukatif antara guru dan peserta didik yang mencakup segi kognitif, afektif dan psikomotor, sebagai upaya mempelajari sesuatu berdasarkan perencanaan sampai dengan tahap evaluasi dan tindak lanjut agar tercapai tujuan pengajaran. Pengelolaan pembelajaran sangat menentukan dalam kegiatan belajar mengajar karena pengelolaan pembelajaran adalah suatu kegiatan yang dilakukan oleh guru dari mulai perencanaan, pelaksanaan kegiatan sampai evaluasi serta progam tindak lanjut yang berlangsung dalam suatu edukatif untuk mencapai tujuan tertentu yaitu pengajaran, hal ini sejalan dengan Sumartini (2000:5) yang menyatakan bahwa "Pengelolaan pembelajaran mencakup semua kegiatan yang secara langsung dimaksudkan untuk mencapai tujuan-tujuan khusus pembelajaran yang meliputi perencanaan pengajaran, pelaksanaan kegiatan belajarmengajar, metode yang digunakan untuk menciptakan situasi belajar mengajar dan penilaian yang fungsinya untuk menetapkan seberapa jauh kertercapaian tujuan proses belajar mengajar."

Profesionalitas guru dalam pengembangan profesi keguruan, seorang pendidik dituntut memiliki tiga aspek performansi tenaga pendidik, diantaranya yaitu :

(1) kemampuan professional yang mencakup (a) penguasaaan pengajaran yang terdiri atas penguasaan bahan yang harus diajarkan, dan konsep-konsep dasar keilmuan dan bahan yang diajarkan; (b) penguasaan dan penghayatan atas landasan dan wawasan pendidik dan keguruan; (c) penguasaan prosesproses pendidikan, keguruan dan pembelajaran siswa;

(2) kemampuan professional guru mencakup (a) penampilan sikap yang positip terhadap keseluruhan tugas guru dan terhadap keseluruhan situasi pendidikan beserta unsur-unsumya; (b) pemahaman, penghayatan dan penampilan nilai-nilai yang seyogyanya dianut oleh seorang guru; (c) kepribadian, 
nilai sikap hidup penampilan upaya untuk menjadikan dirinya sebagai panutan dan teladan bagi siswanya (Sanusi, 1991).

Variabel Kualitas Pendidik dalam penelitian ini adalah tingkat kemampuan atau kecerdasan guru yang dinilai melalui kompetensi pedagogik, profesional, kepribadian dan sosial, nilai ini menurut ukuran yang dihitung dalam data Neraca Pendidkan Daerah Kemendikbud, adalah Nilai Uji Kompetensi Guru (NUKG) masing-masing kabupaten/kota di Provinsi Aceh pada setiap tahun, yang dihitung dalam satuan tingkat pencapaian.

Terdapat 4 (empat) kompetensi yang menjadi indikator pengukurnya, yaitu kompetensi akademik, kompetesi pedagogik, kompetensi sosial, dan kompetensi profesi guru. Uji kompetensi merupakan satusatunya cara untuk mengetahui seberapa kompeten seseorang guru terhadap profesinya. Namun, guru yang telah memiliki sertifikasi tidak perlu diuji kembali. Dan guru itu sebagai profesi, dan ini amanah undangundang.

Pasal 10 ayat (1) Undang-Undang Nomor 14 tahun 2005 tentang Guru dan Dosen mengamanatkan bahwa guru harus memiliki kompetensi pedagogik, kompetensi kepribadian, kompetensi sosial, dan kompetensi profesional. Keempat kompetensi bersifat holistik dan merupakan suatu kesatuan yang menjadi ciri guru profesional.

\section{d. Pengertian Akreditasi Sekolah}

Akreditasi adalah kegiatan penilaian kelayakan program dan/atau satuan pendidikan berdasarkan kriteria yang telah ditetapkan sebagaimana dinyatakan pada UU Nomor 20/2003 tentang Sistem Pendidikan Nasional, pasal 1 ayat (22). Akreditasi sekolah/madrasah adalah proses penilaian secara komprehensif terhadap kelayakan satuan atau program pendidikan, yang hasilnya diwujudkan dalam bentuk pengakuan dan peringkat kelayakan dalam bentuk yang diterbitkan oleh suatu lembaga yang mandiri dan profesional.

Sabar Budi Raharjo, dkk, (2018), menyatakan: "Akreditasi sekolah dapat dijadikan sebagai ukuran ketercapai an mutu suatu sekolah karena akreditasi adalah salah satu instrumen dari pemerintah untuk mengetahui kondisi mutu pendidikan baik pada tingkat kabupaten/kota, tingkat provinsi, maupun tingkat nasional. Lembaga yang mendapat mandat secara independen untuk melakukan akreditasi terhadap delapan Standar Nasional Pendidikan (SNP) pada satuan pendidikan yaitu Badan Akreditasi Nasional Sekolah/Madrasah (BAN S/M)".

Kelayakan program dan satuan pendidikan mengacu pada SNP. SNP adalah kriteria minimal tentang sistem pendidikan di seluruh wilayah hukum Negara Kesatuan Republik Indonesia. Oleh karena itu, SNP harus dijadikan acuan guna memetakan secara utuh profil kualitas sekolah/madrasah. Peraturan Pemerintah No. 19 Tahun 2005 tentang Standar Nasional Pendidikan pasal 2 ayat (1) menyebutkan bahwa lingkup SNP meliputi: 1). standar isi, 2). standar proses, 3). standar kompetensi lulusan, 4). standar pendidik dan tenaga kependidikan, 5). standar sarana dan prasarana, 6). standar pengelolaan, 7). standar pembiayaan; dan 8).standar penilaian pendidikan.

Berdasarkan BAN (2018) Akreditasi sekolah/madrasah yang komprehensif dapat memetakan secara utuh profil sekolah/madrasah, memiliki fungsi sebagai berikut: 1) Pengetahuan yaitu sebagai informasi bagi semua pihak tentang kelayakan sekolah/ madrasah dilihat dari berbagai unsur terkait yang mengacu pada standar nasional pendidikan beserta indikator-indikatornya. 2) Akuntabilitas yaitu sebagai bentuk pertanggungjawaban sekolah/ madrasah kepada publik, apakah layanan yang dilakukan dan diberikan oleh sekolah/madrasah telah memenuhi harapan atau keinginan masyarakat. 3) Pembinaan dan pengembangan yaitu sebagai dasar bagi sekolah/ madrasah, pemerintah, dan masyarakat dalam upaya peningkatan atau pengembangan mutu sekolah/madrasah.

Prinsip-prinsip Akreditasi Prinsip-prinsip yang diterapkan dalam pelaksanaan akreditasi sekolah/madrasah adalah objektif, komprehensif, adil, transparan, akuntabel, dan profesional.

Variabel Akreditasi Sekolah dalam penelitian ini mengukur tingkat pencapaian Akrediditasi rata-rata SMA di suatu wilayah (Kabupaten/Kota) di Provinsi Aceh pada tahun pengamatan, yaitu proses penilaian secara komprehensif terhadap kelayakan satuan atau program pendidikan, yang hasilnya diwujudkan dalam bentuk pengakuan dan peringkat kelayakan dalam bentuk yang diterbitkan oleh suatu lembaga yang mandiri dan profesional. Yaitu Badan Akreditasi Nasional. Penentuan Tingkat Akreditasi, didasarkan perbandingan yang capai semua SMA di Suatu Daerah yang dihitung, dibandingkan dengan Akreditasi idealnya (A).

Misalnya di Kabupaten-A, tahun 2019 terdapat 20 SMA, dimana 10 SMA Akreditasi A (diberikan nilai atau poin-4), 5 Akreditasi-B (diberikan poin-3), dan 4 Akreditasi-C (diberikan poin-2), serta ada 1 SMA Non- 
Akreditasi (dengan poin- Maka Tingkat Pencapaian Akreditasi pada Daerah tersebut adalah: $(10 \times 4)+(5 \times 3)+(4 \times 2)+(1 \times 1)$

Tingkat Akreditasi $=$ ---------------------------- x $100=80,00$

$20 \times 4$

(Sumber Data: Neraca Pendidkan Darah Kemendikbud, 2017-2019)

Adapun akreditasi Sekolah Menengah atas (SMA) setiap kabupaten/kota di Provinsi Aceh selama tahun 2017-2019 dapat dilihat pada tabel 2.1 dibawah ini:

Tabel 1. Akreditasi Sekolah Menengah Atas di Kabupeten Bireuen

\begin{tabular}{|c|l|c|c|c|}
\hline \multirow{2}{*}{ No } & \multirow{2}{*}{ Daerah } & \multicolumn{3}{|c|}{ Tingkat Akreditasi } \\
\cline { 3 - 5 } & & 2017 & 2018 & 2019 \\
\hline $\mathbf{0}$ & Prov. Aceh & $\mathbf{7 8 , 2 9}$ & $\mathbf{8 0 , 5 8}$ & $\mathbf{7 9 , 7 2}$ \\
\hline 1 & Kab. Aceh Besar & 77,33 & 81,25 & 82,32 \\
\hline 2 & Kab. Pidie" & 85,71 & 87,50 & 88,39 \\
\hline 3 & Kab. Aceh Utara & 78,13 & 81,13 & 81,36 \\
\hline 4 & Kab. Aceh Timur & 80,47 & 83,33 & 82,50 \\
\hline 5 & Kab. Aceh Tengah & 78,75 & 81,58 & 82,89 \\
\hline 6 & Kab. Aceh Barat & 82,14 & 82,14 & 80,95 \\
\hline 7 & Kab. Aceh Selatan & 78,03 & 79,55 & 79,55 \\
\hline 8 & Kab. Aceh Tenggara & 69,35 & 76,00 & 71,43 \\
\hline 9 & Kab. Simeulue & 73,00 & 73,00 & 71,00 \\
\hline 10 & Kab. Bireuen & 73,57 & 75,00 & 73,57 \\
\hline 11 & Kab. Aceh Singkil & 76,56 & 84,62 & 80,36 \\
\hline 12 & Kab. Aceh Tamiang & 85,19 & 87,50 & 80,56 \\
\hline 13 & Kab. Nagan Raya & 71,43 & 80,88 & 79,17 \\
\hline 14 & Kab. Aceh Jaya & 66,18 & 81,25 & 80,77 \\
\hline 15 & Kab. Aceh Barat Daya & 78,13 & 81,67 & 81,67 \\
\hline 16 & Kab. Gayo Lues & 81,67 & 81,67 & 81,67 \\
\hline 17 & Kab. Bener Meriah & 71,74 & 71,74 & 69,57 \\
\hline 18 & Kab. Pidie Jaya & 82,14 & 86,54 & 84,62 \\
\hline 19 & Kota Sabang & 100,00 & 100,00 & 100,00 \\
\hline 20 & Kota Banda Aceh & 89,66 & 88,39 & 86,67 \\
\hline 21 & Kota Lhokseumawe & 82,69 & 91,67 & 91,67 \\
\hline 22 & Kota Langsa & 80,56 & 80,56 & 80,56 \\
\hline 23 & Kota Subulussalam & 76,92 & 84,09 & 83,33 \\
\hline
\end{tabular}

Sumber: https://npd.kemdikbud.go.id/

\section{e. Pengertian Kualitas Lulusan}

Dalam konteks pendidikan pengertian kualitas mencakup input, proses, dan output pendidikan (Umaidi, 1999). Kualitas lulusan pendidikan di Indonesia mengacu pada Standar Kompetensi Lulusan dalam Standar Nasional Pendidikan. Kompetensi lulusan sebagaimana diamanatkan dalam PP Nomor 13 Tahun 2015 tentang perubahan atas PP Nomor 19 Tahun 2005 tentang Standar Nasional Pendidikan, dan diatur lebih lanjut dalam Peraturan Menteri Pendidikan dan Kebudayaan (Permendikbud) Nomor 54 Tahun 2013 tentang Standar Kompetensi Lulusan Dasar dan Menengah, yang dikembangkan untuk memenuhi tuntutan kebutuhan kompetensi pada abad ke-21, persaingan yang semakin global, dan kebutuhan lokal serta nasional.

Untuk mengetahui kesesuaian dan pencapaian Standar Kompetensi Lulusan, perlu dilakukan monitoring dan evaluasi. Kesesuaian Standar Kompetensi Lulusan dimonitor dan dievaluasi secara berkala dan berkelanjutan terhadap kebutuhan lulusan pendidikan dan kebutuhan peserta didik, baik lokal, nasional, maupun global. Sementara itu, pencapaian Standar Kompetensi Lulusan dimonitor dan dievaluasi secara berkala terhadap lulusan dari setiap satuan pendidikan. Evaluasi dilakukan terhadap kesesuaian sumber daya dan proses pembelajaran yang digunakan pada satuan pendidikan tertentu (Sani, 2015).

Konsep mutu lulusan sebagaimana ditegaskan Uwes adalah "gambaran dan karakteristik menyeluruh pendidikan yang menunjukkan kemampuannya dalam memenuhi kebutuhan yang diharapkan atau yang tersirat." Dengan kata lain, mutu pendidikan mencakup input, proses, dan output pendidikan. Sementara input pendidikan adalah segala sesuatu yang harus tersedia karena dibutuhkan untuk berlangsungnya proses.

Pendidikan dikatakan bermutu tinggi apabila pengkoordinasian dan penyerasian serta pemaduan input sekolah (guru, siswa, kurikulum, uang, peralatan, dsb.) dilakukan secara harmonis, sehingga mampu menciptakan situasi pembelajaran yang menyenangkan (enjoyable learning), mampu mendorong motivasi dan minat belajar, dan benar-benar mampu memberdayakan peserta didik. Kata memberdayakan mengandung arti bahwa peserta didik tidak sekadar menguasai pengetahuan yang diajarkan oleh gurunya, 
akan tetapi pengetahuan tersebut juga telah menjadi muatan nurani peserta didik, dihayati, diamalkan dalam kehidupan sehari-hari, dan yang lebih penting lagi peserta didik tersebut mampu belajar secara terus menerus (mampu mengembangkan dirinya).

Kualitas lulusan atau output yang diteliti dalam penelitian ini adalah prestasi belajar peserta anak didik, yang menunjukkan pencapaian yang tinggi dalam hasil kemampuan akademik, yaitu nilai ujian yang diakui secara nasional, diambil indikatornya adalah hasil Ujian Akhir Nasional (UAN) yang diperoleh rata-rata siswa di Sekolah. Dalam data penelitian ini adalah rata-rata UN siswa SMA setiap Kabupaten/Kota di Provinsi Aceh pada tahun pengamatan.

\section{Metodologi Penelitian (Methodology)}

\section{a. Metode Penelitian dan Unit Analisis}

Penelitian ini menggunakan paradigma kuantitatif (quantitative paradigm) atau penelitian kuantitatif. Penelitian ini menekankan pada pengujian teori-teori melalui pengukuran variabel-variabel penelitian dengan angka dan melakukan analisis data dengan prosedur statistik. Penelitian dengan pendekatan deduktif yang bertujuan untuk menguji hipotesis merupakan tipe penelitian yang menggunakan paradigma kuantitatif (Indiantono dan Sutono, 2013). Sedangkan Cresweel (2010) menyatakan bahwa pendekatan kuantitatif adalah pengukuran data kuantitatif dan statistik objektif melalui perhitungan ilmiah berasal dari sampel orang-orang atau penduduk yang diminta menjawab atas sejumlah pertanyaan tentang survey untuk menentukan frekuensi dan prosentase tanggapan mereka.

Metode yang digunakan adalah survei eksplanasi (explanatory survey method). Metode explanatory survey merupakan metode penelitian yang dilakukan pada populasi besar maupun kecil, sehingga ditemukan deskripsi dan hubungan-hubungan antar variabel (Sugiyono, 2011). Metode ini dibatasi pada pengertian survey sampel yang bertujuan menguji hipotesis yang telah dirumuskan sebelumnya (testing research).

Penelitian survey ini merupakan studi bersifat kuantitatif dan umumnya menggunakan kuesioner sebagai alat pengumpul datanya. Dalam penelitian ini akan digunakan statistika yang tepat untuk tujuan hubungan sebab akibat. Sehingga metode penelitian dengan pendekatan penelitian eksplanasi asosiatif, dengan fokus penelitian terletak pada penjelasan hubungan-hubungan antar variabel. Dengan digunakannya metode dan pendekatan yang telah disebutkan di atas peneliti melakukan pengamatan untuk memperoleh gambaran antar variabel serta menganalisis apakah terdapat pengaruh anggaran pendidikan, kualitas pendidik dan akreditasi sekolah terhadap kualitas lulusan pada SMA se-Provinsi Aceh, tahun 2017-2019.

Penelitian ini menggunakan data sekunder yaitu data yang diperoleh dari sumber kedua atau sekunder (Bungin, 2001). Keseluruhan data yang dikumpulkan diperoleh dari Neraca Pendidikan Daerah Kemendikbud, selama tahun 2017-2019. Sehingga data penelitian berupa data panel, yakni horizon waktu 3 tahun dengan dipaparkan semua Kabupaten/Kota di Aceh. Terdapat sejumlah 69 unit data.

\section{b. Operasional Variabel Penelitian}

Tabel 2. Operasional Variabel Penelitian

\begin{tabular}{|c|c|c|c|}
\hline Variabel & Dimensi & Indikator & Skala \\
\hline $\begin{array}{c}\text { Anggaran } \\
\text { pendidikan }\left(\mathrm{X}_{1}\right)\end{array}$ & $\begin{array}{l}\text { a. Dana Pendidikan } \\
\text { b. Dana Pembangunan } \\
\text { Infrastruktur }\end{array}$ & $\begin{array}{l}\text { 1. Kebutuhan dana utk kualitas pendidikan, } \\
\text { 2. Pembangunan infrastruktur } \\
\text { 3. Sarana dan prasarana pendidikan, dan } \\
\text { 4. Dana peningkatan kompetensi guru }\end{array}$ & Rasio \\
\hline $\begin{array}{c}\text { Kualitas } \\
\text { Pendidik }\left(\mathrm{X}_{2}\right)\end{array}$ & $\begin{array}{l}\text { Nilai Uji Kompetensi Guru } \\
\text { (UKG) }\end{array}$ & $\begin{array}{l}\text { 1. kompetensi pedagogik, } \\
\text { 2. kompetensi profesional, } \\
\text { 3. kompetensi kepribadian dan } \\
\text { 4. Kompetensi sosial, } \\
\end{array}$ & Rasio \\
\hline $\begin{array}{c}\text { Akreditasi } \\
\text { Sekolah }\left(\mathrm{X}_{3}\right) \\
\end{array}$ & Peringkat Akreditasi & $\begin{array}{l}\text { Hasil Pencapaian dalam Akreditasi terhadap } \\
\text { Akreditasi Ideal }\end{array}$ & Rasio \\
\hline $\begin{array}{l}\text { Kualitas lulusan } \\
\text { (Y) }\end{array}$ & Prestasi belajar peserta didik & Nilai Ujian Nasional (UN) & Rasio \\
\hline
\end{tabular}

\section{c. Metode Analisis}

Pendekatan yang digunakan dalam penelitian ini adalah pendekatan kuantitatif dalam menganalisis data digunakan Teknik analisis regresi linier berganda. Sekaran (2011:299), menerangkan bahwa analisis regresi berganda dilakukan untuk menguji pengaruh simultan dari beberapa variabel bebas terhadap suatu variabel terikat yang berskala minimal interval. 
Adapun model regresi penelitian ini berbentuk: $Y=a+b_{1} X_{1}+b_{2} X_{2}+b_{3} X_{3}+\varepsilon$

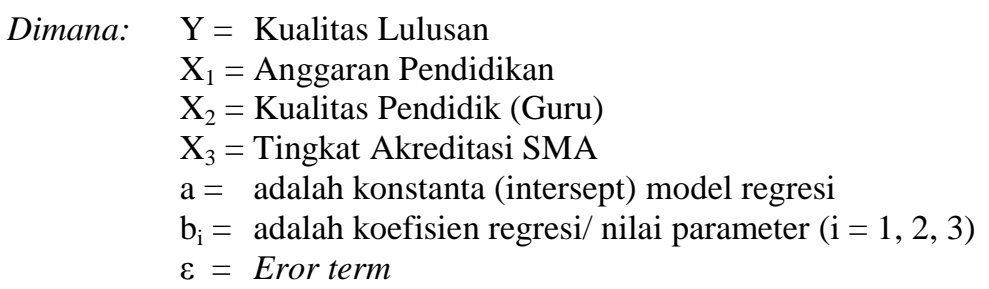

Model regresi data panel yang akan diestimasi membutuhkan asumsi terhadap intersep, slope dan variabel gangguannya. Agus (2007), menyatakan ada beberapa kemungkinan yang akan muncul atas adanya asumsi terhadap intersep, slope dan variabel gangguannya.

1. Diasumsikan intersep dan slope adalah tetap sepanjang periode waktu dan seluruh entitas. Perbedaan intersep dan slope dijelaskan oleh variabel gangguan (residual).

2. Diasumsikan slope adalah tetap tetapi intersep berbeda antar entitas.

3. Diasumsikan slope tetap tetapi intersep berbeda baik antar waktu maupun antar individu.

Gujarati dan Porter (2009), menyatakan teknik mengestimasi model data panel sebagai berikut:

1. Model Pooled OLS - semua sampel observasi dikumpulkan menjadi satu dimana tindakan ini menghilangkan cross-section dan runtun waktu. Model ini sering juga disebut Model koefisien konstan (Constant Coefficient Model).

2. Model Efek Tetap Kwadrat Terkecil Variabel Boneka (Fixed Effects Least Squares Dummy Variable Model - LSDV) - semua data digabungkan tetapi diijinkannya crosssection memiliki peubah boneka.

3. Model Efek Tetap dalam kelompok (Fixed Effects Within-Group Model) - semua data digabungkan tetapi unit observasi (objek) mengekspresikan setiap peubah sebagai selisih dari rata-ratanya dan diestimasi menggunakan metoda kwadrat terkecil.

4. Model Efek Acak (Random Effects Model) - seperti model LSDV dimana setiap observasi memiliki nilai intersep dan diasumsikan diambil secara acak dari populasi yang lebih besar.

Menurut Usman (2006:318), pemilihan metode Fixed Effect atau metode Random Effect dapat dilakukan dengan pertimbangan tujuan analisis, atau ada pula kemungkinan data yang digunakan sebagai dasar pembuatan model, hanya dapat diolah oleh salah satu metode saja akibat berbagai persoalan teknis matematis yang melandasi perhitungan. Menurut Agus (2007: 258), ada tiga uji untuk memilih teknik estimasi data panel, dapat menerapkan ketiga metode, yakni Uji statistik F dari Chow, Uji Hausmann, dan Uji Lagrange Multiplier. Dalam hal ini peneliti hanya menggunakan uji F (uji Chow). Uji Statistik F (Uji Chow) digunakan untuk memilih antara metode Commom Effect atau metode Fixed Effect atau untuk mengetahui model mana yang lebih baik dalam pengujian data panel, bisa dilakukan dengan penambahan variabel dummy sehingga dapat diketahui bahwa intersepnya berbeda dapat diuji dengan uji Statistik F. Uji ini digunakan untuk mengetahui apakah teknik regresi data panel dengan metode Fixed Effect lebih baik dari regresi model data panel tanpa variabel dummy atau metode Common Effect. Hipotesis nol pada uji ini adalah bahwa intersep sama, atau dengan kata lain model yang tepat untuk regresi data panel adalah Common Effect, dan hipotesis alternatifnya adalah intersep tidak sama atau model yang tepat untuk regresi data panel adalah Fixed Effect.

\section{Hasil dan Pembahasan (Results and Discussion)}

\section{a. Data Penelitian}

Besaran anggaran pendidikan yang mencapai 20\% dari APBD dan APBN dalam rangka menjamin peningkatan kualitas tenaga pendidikan di Negara Republik Indonesia.

Tabel 3. Anggaran Pendidikan di Provinsi Aceh Tahun 2017 - 2019

\begin{tabular}{|c|c|c|c|}
\hline Data Provinsi Aceh & \multicolumn{3}{|c|}{ Angaran Pendidikan (Miliar) } \\
\hline Tahun & 2017 & 2018 & 2019 \\
\hline Dana (Miliar Rupiah) & $2.723,38$ & $2.723,38$ & $2.723,38$ \\
\hline
\end{tabular}

Meninjau kualitas pendidik dalam hal ini adalah kualitas guru, indikatornya adalah dilihat dari hasil Uji Kompetensi Guru (UKG) yang dilaksanakan oleh Kementerian Pendidikan dan Kebudayaan. Uji 
Kompetensi Guru (UKG) merupakan penilaian kompetensi guru yang juga berfungsi sebagai penilaian kinerja guru dalam rangka pembinaan dan pengembangan profesi yang pada pemetaan kompetensi.

Nilai rata-rata UKG dan IPM Provinsi Aceh tidak lebih baik dibandingkan dengan nilai rata-rata Nasional. Berdasarkan Neraca Pendidikan Daerah diperoleh bahwa nilai rata-rata UKG Provinsi Aceh adalah 48,33 pada tahun 2018 dan naik sedikit tahun 2019 menjadi 51,05. BPS juga melaporkan bahwa IPM Provinsi Aceh Tahun 2018 berada sedikit lebih rendah dibandingkan dengan IPM Nasional Tahun 2018 yaitu 71,19.

Akreditasi sekolah dapat dijadikan sebagai ukuran ketercapaian mutu suatu sekolah karena akreditasi adalah salah satu instrumen dari pemerintah untuk mengetahui kondisi mutu pendidikan baik pada tingkat kabupaten/kota, tingkat provinsi, maupun tingkat nasional. Akreditasi sekolah SLTA di Provinsi Aceh, terus menunjukkan peningkatan dari waktu ke waktu. Meninjau data Neraca Pendidikan Daerah Kemdikbud untuk 3 tahun terakhir, yakni tahun 2017-2019 adanya peningkatan. Dengan mengkotagorikan Akreditasi A dengan nilai 4, B dengan nilai 3, C dengan nilai 2, dan Non Akreditasi dengan nilai 1, maka tingkat Akreditasi Sekolah jenjang SMA di Provinsi Aceh tahun 2017-2019 adalah sebagai berikut:

Tabel 4. Tingkat Akreditasi SMA di Provinsi Aceh Tahun 2017 - 2019

\begin{tabular}{|c|c|c|c|}
\hline Data Provinsi Aceh & \multicolumn{3}{|c|}{ Tingkat Akreditasi } \\
\hline Tahun & 2017 & 2018 & 2019 \\
\hline Tingkat Akreditasi SMA & 78,29 & 80,58 & 79,72 \\
\hline Sumber : https://npd.kemdikbud.go.id/
\end{tabular}

Selain mempengaruhi IPM, rendahnya kinerja dan kompetensi guru juga dapat mempengaruhi nilai rata-rata Ujian Nasional (UN) khususnya pada jenjang Sekolah Menengah Atas (SMA). Ujian Nasional (UN) merupakan penilaian hasil belajar oleh pemerintah yang bertujuan untuk menilai pencapaian kompetensi peserta didik secara Nasional pada mata pelajaran tertentu. Berdasarkan data yang dirilis oleh Puspendik pada Bulan September 2019, diperoleh data bahwa nilai rata-rata UN SMA IPA di Provinsi Aceh adalah 43,11 dan Nasional adalah 53,00. Selanjutnya, rata-rata UN SMA IPS Tahun 2019 adalah 39,22 dan Nasional 47,42. Tetapi setiap tahun adanya kecenderungan peningkatan. Sebagaimana disajikan datanya pada tabel 5 .

Tabel 5. Nilai Ujian Nasional Provinsi Aceh tahun 2017 - 2019

\begin{tabular}{|l|l|l|l|l|l|l|l|l|c|}
\hline \multirow{2}{*}{ Daerah } & \multicolumn{3}{|c|}{ UN SMA TAHUN 2017} & \multicolumn{3}{|c|}{ UN SMA TAHUN 2018} & \multicolumn{3}{c|}{ UN SMA TAHUN 2019 } \\
\hline & IPA & IPS & Rata-rata & IPA & IPS & Rata-rata & IPA & IPS & Rata-rata \\
\hline Prov. Aceh & 41,96 & 38,67 & 40,32 & 40,12 & 37,27 & 38,70 & 43,11 & 39,22 & 41,17 \\
\hline
\end{tabular}

Sumber : Puspendik pada Bulan September 2019

\section{b. Hasil Analisis Data Penelitian}

Data yang digunakan dalam analisis masalah tentang Pengaruh Anggaran Pendidikan, Kualitas Pendidik dan Akreditasi Sekolah terhadap Kualitas Lulusan pada SMA di Provinsi Aceh ini menggunakan data sekunder dari Neraca Pendidikan Daerah yang diambil dari situs : https://npd.kemdikbud.go.id. Yakni data selama tahun 2018 - 2019 untuk 23 kabupaten di daerah provinsi Aceh. Sehingga analisis data adalah data panel antara tahun pengamatan (2018-2019) pada 23 daerah kabupaten di Provinsi Aceh.

Sebelum melakukan alat analisis regresi berganda (Multiple Regression), dan pengujian hipotesis, terlebih dahulu dilakukan pengujian asumsi klasik yang bertujuan untuk memastikan bahwa model secara statistik (analisis regresi) yang digunakan dalam analisis masalah dapat digunakan atau tidak. Apabila uji asumsi klasik telah terpenuhi, maka alat uji statistik analisis regresi dapat dipergunakan.

\section{Uji Normalitas}

Untuk pengujian normalitas data dalam penelitian ini dideteksi melalui analisa grafik dan statistik yang dihasilkan melaui perhitungan regresi dengan menggunakan SPSS. Model yang paling baik adalah apabila datanya terdistribusi normal atau mendekati normal. Jika data menyebar di sekitar garis diagonal dan mengikuti arah diagonal, maka model regresi memenuhi asumsi normalitas. Sebaliknya, jika data menyebar jauh dari garis diagonal dan atau tidak mengikuti arah garis diagonal, maka model regresi tidak memenuhi asumsi normalitas (Sugiyono, 2003). Hasil Pengujian Normalitas dapat dilihat pada gambar 1. Dari grafik kurva normal, dapat disimpulkan bahwa data yang digunakan menunjukkan normal. Singgih Santoso (2009:342) menyatakan bahwa jika data menyebar normal di sekitar garis diagonal dan mengikuti arah garis diagonal, maka model regresi memenuhi asumsi normalitas. Sebaliknya jika data menyebar jauh dari garis 
diagonal, maka model regresi tidak memenuhi asumsi normalitas. Uji normalitas dilakukan untuk mengetahui simetris tidaknya distribusi data.

Normal P-P Plot of Regression Standardized Residual

Dependent Variable: Kualitas Lulusan

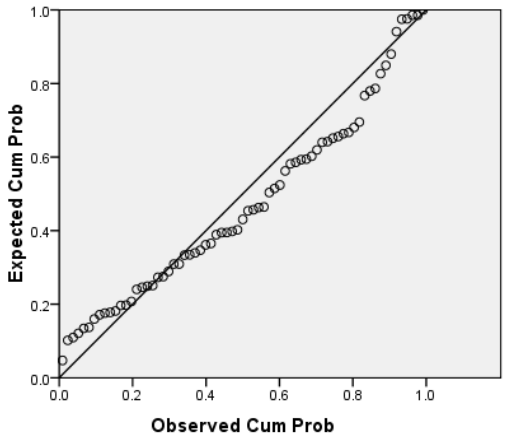

Gambar 1 Uji Normalitas

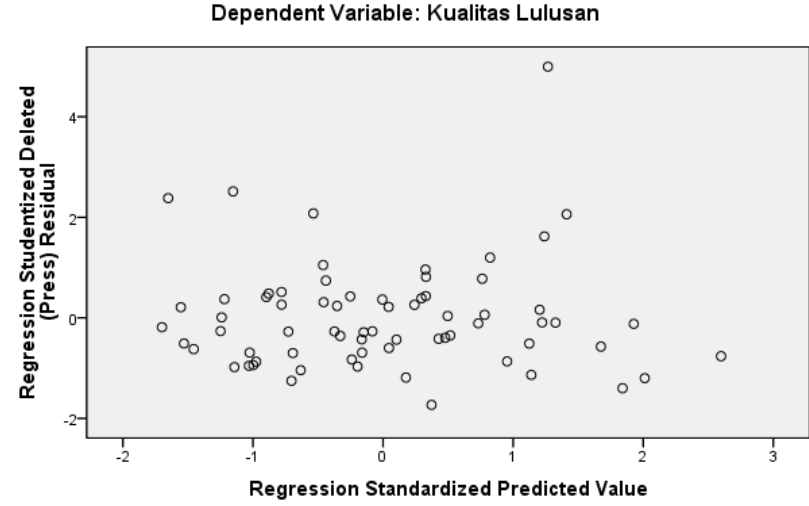

Gambar 2 Uji Heterokedastisitas

\section{Uji Heterokedastisitas}

Menurut Santoso (2009), heterokedastisitas terjadi bila kesalahan atau residual dari model yang diamati tidak memiliki varian yang konstan dari satu observasi ke observasi lainnya. Deteksi dapat dilakukan dengan analisa grafis, dimana jika terdapat pola tertentu pada scatterplot maka terjadi heterokedastisitas. Uji heterokedatisitas dilakukan untuk mengetahui penyebaran varians gangguan. Hasil pengujian heterokedatisitas data dalam penelitian ini menggunakan SPSS dengan mengamati pola pada scatterplot, hasilnya dapat dilihat pada gambar 2. Yang telihat bahwa titik-titik menyebar secara acak (random) serta tersebar di atas maupun di bawah angka 0 pada sumbu Y, sehingga dapat disimpulkan bahwa tidak terjadi heterokedastisitas pada model regresi dan layak dipakai untuk memprediksi keputusan memilih berdasarkan masukan dari variabel bebasnya.

\section{Uji Multikolinearitas}

Uji Multikolinearitas Menurut Santoso (2009) suatu model regresi dikatakan bebas dari masalah tersebut jika nilai Variance Inflation Factor (VIF) dan Tolerance adalah : a) Mempunyai nilai Variance Inflation Factor di bawah 10 , b) Mempunyai angka Tolerance diatas 0, c) Besaran korelasi antar variabel independen haruslah lemah (di bawah 0,5).

Uji multikollinieritas dilakukan untuk mengetahui ada tidaknya korelasi antar varibel bebas yang disebut dengan multikolonieritas. Pada model regresi yang baik tidak terjadi korelasi di antara variabel bebas. Hasil pengujian multikollinieritas data dalam penelitian ini menggunakan alat bantu SPSS, hasilnya dapat dilihat pada tabel berikut :

Tabel 6. Hasil Uji Multikolinearitas

\begin{tabular}{|c|c|c|c|c|c|c|}
\hline \multirow{2}{*}{\multicolumn{2}{|c|}{ Model }} & \multicolumn{2}{|c|}{ Unstandardized Coefficients } & \multirow[b]{2}{*}{ Sig. } & \multicolumn{2}{|c|}{ Collinearity Statistics } \\
\hline & & $\mathrm{B}$ & Std. Error & & Tolerance & VIF \\
\hline 1 & (Constant) & 18.843 & 5.613 & .001 & & \\
\hline & Anggaran Pendidikan & -.003 & .003 & .302 & .925 & 1.081 \\
\hline & Kualitas Pendidik & .245 & .085 & .005 & .837 & 1.195 \\
\hline & Tingkat Akreditasi & .126 & .061 & .043 & .897 & 1.115 \\
\hline
\end{tabular}

a. Predictors: (Constant), Tingkat Akreditasi, Anggaran Pendidikan, Kualitas Pendidik

b. Dependent Variable: Kualitas Lulusan

Dari tabel 6 dapat dilihat bahwa variabel bebas yang memiliki nilai Variance Inflation Factor dibawah 10 dan mempunyai angka Tolerance diatas 0 , mendekati 1 . Jadi dapat disimpulkan bahwa tidak ada multikollinieritas antar variabel bebas dalam model regresi.

\section{Hasil Analisis Regresi}

Dalam penelitian ini model analisis dengan analisi regresi berganda (Multiple Regression) yang menentukan pengaruh variabel Anggaran Pendidikan $\left(\mathrm{X}_{1}\right)$, Kualitas Pendidik $\left(\mathrm{X}_{2}\right)$, dan Tingkat Akreditasi $\left(\mathrm{X}_{3}\right)$, terhadap Kualitas lulusan (Y) SMA di Provinsi Aceh, dengan kasus data tahun 2017-2019. 
Dengan model: $Y=f(X 1, X 2, X 3)=c+b_{1} X_{1}+b_{2} X_{2}+b_{3} X_{3}+e$.

Adapun pembuktian hipotesis secara simultan (keseluruhan) dapat dilihat pada tabel berikut ini:

Tabel 7. Uji Model Analisis Regresi Secara Simultan

\begin{tabular}{|c|c|c|c|c|c|}
\hline Model & Sum of Squares & df & Mean Square & F & Sig. \\
\hline Regression & 210.339 & 3 & 70.113 & 7.514 & $.000^{\mathrm{a}}$ \\
\hline Residual & 606.478 & 65 & 9.330 & & \\
\hline Total & 816.817 & 68 & & & \\
\hline
\end{tabular}

a. Predictors: (Constant), Tingkat Akreditasi, Anggaran Pendidikan, Kualitas Pendidik

b. Dependent Variable: Kualitas Lulusan

Hipotesis Uji:

Ho: $b_{i}=0$, Terdapat salah satu variabel bebas yang tidak signifikan, sehingga model regresi tidak signifikans secara simultan

Ha: $b_{i} \neq 0$, Semua variabel bebas yang signifikan, sehingga model regresi signifikans secara simultan, atau semua variabel bebas mempengaruhi variabel tak bebas.

Berdasarkan hasil uji $\mathrm{F}$ diperoleh nilai $\mathrm{F}_{\text {hitung }}$ sebesar 7,514, tampak dalam kolom-6, tabel 7 diatas, yang menyatakan nilai signifikansinya pada 0.000. Dengan demikian dapat disimpulkan bahwa probabilitas dalam penelitian ini lebih kecil dari $0,05 \%$ maka hipotesis nol (Ho) ditolak, yang berarti bahwa variabel Anggaran Pendidikan, Kualitas Pendidik, dan Tingkat Akreditasi, terhadap Kualitas lulusan SMA di Aceh.

\section{Uji Parsial}

Selanjutnya dilakukan pengujian hipotesis yang diajukan selanjutnya diuji untuk menjawab masalah penelitian yang dirumuskan. Yaitu, a) Apakah variabel anggaran pendidikan $\left(\mathrm{X}_{1}\right)$ berpengaruh terhadap Kualitas Lulusan $(\mathrm{Y})$, b) Apakah variabel Kualitas pendidik $\left(\mathrm{X}_{2}\right)$ berpengaruh terhadap Kualitas Lulusan $(\mathrm{Y})$, dan c) Apakah variabel Tingkat Akreditasi $\left(\mathrm{X}_{3}\right)$ berpengaruh terhadap Kualitas Lulusan (Y) SMA di Provinsi Aceh, dengan kasus data tahun 2017-2019.

Dengan hasil olahan data diperoleh berikut ini (Tabel 8):

Tabel 8. Taksiran Koefisien Model Regresi dan Pengujiannya

\begin{tabular}{|c|c|c|c|c|c|}
\hline \multirow[b]{2}{*}{ Model } & \multicolumn{2}{|c|}{ Unstandardized Coefficients } & \multirow{2}{*}{$\frac{\text { Standardized Coefficients }}{\text { Beta }}$} & \multirow[b]{2}{*}{$\mathrm{t}$} & \multirow[b]{2}{*}{ Sig. } \\
\hline & B & Std. Error & & & \\
\hline (Constant) & 18.843 & 5.613 & & 3.357 & .001 \\
\hline Anggaran Pendidikan & -.003 & .003 & -.116 & -1.041 & .302 \\
\hline Kualitas Pendidik & .245 & .085 & .337 & 2.885 & .005 \\
\hline Tingkat Akreditasi & .126 & .061 & .233 & 2.062 & .043 \\
\hline
\end{tabular}

a. Dependent Variable: Kualitas Lulusan Sumber; Hasil olahan data dengan SPSS

a) Pengaruh Anggaran pendidikan $\left(\mathrm{X}_{1}\right)$ berpengaruh terhadap Kualitas Lulusan (Y)

Bentuk Hipotesis:

Ho: $\quad b_{1}=0, \quad$ Variabel Anggaran Pendidikan $\left(\mathrm{X}_{1}\right)$ tidak berpengaruh terhadap Kualitas Lulusan $(\mathrm{Y})$

Ha: $\quad b_{1} \neq 0, \quad$ Variabel Anggaran Pendidikan $\left(\mathrm{X}_{1}\right)$ berpengaruh terhadap Kualitas Lulusan (Y)

Statistik uji menggunakan statistik t, dimana hasil t-hitung dari tabel 8 diatas, diperoleh t-hitung $=-1,041$, dengan nilai signifikansi 0,302 . Jika ditetapkan nilai probabilitas kesalahan uji dalam penelitian sebesar $5 \%$ $(\alpha=5 \%=0,05)$, maka hasil uji menyatakan koefisien regresi variabel anggaran pendidikan $\left(b_{1}\right)$ tidak signifikans. Yang menyatakan Anggaran Pendidikan tidak berpengaruh terhadap Kualitas Lulusan.

b) Pengaruh Kualitas Pendidik $\left(\mathrm{X}_{2}\right)$ berpengaruh terhadap Kualitas Lulusan (Y)

Bentuk Hipotesis:

Ho: $b_{2}=0, \quad$ Variabel Kualitas pendidik $\left(\mathrm{X}_{2}\right)$ tidak berpengaruh terhadap Kualitas Lulusan $(\mathrm{Y})$

Ha: $b_{2} \neq 0, \quad$ Variabel Kualitas pendidik $\left(\mathrm{X}_{2}\right)$ berpengaruh terhadap Kualitas Lulusan (Y)

Statistik uji menggunakan statistik t, dimana hasil t-hitung dari tabel 8 diatas, diperoleh t-hitung $=2,885$, dengan nilai signifikansi 0,005 . Jika ditetapkan nilai probabilitas kesalahan uji dalam penelitian sebesar $5 \%$ 
$(\alpha=5 \%=0,05)$, maka hasil uji menyatakan koefisien regresi variabel Kualitas pendidik $\left(b_{2}\right)$ signifikans. Yang Menyatakan Kualitas pendidik berpengaruh signifikans terhadap Kualitas Lulusan.

c) Pengaruh Tingkat Akreditasi $\left(\mathrm{X}_{3}\right)$ berpengaruh terhadap Kualitas Lulusan $(\mathrm{Y})$

Bentuk Hipotesis:

Ho: $b_{3}=0$,

Variabel Tingkat Akreditasi $\left(\mathrm{X}_{3}\right)$ tidak berpengaruh terhadap Kualitas Lulusan $(\mathrm{Y})$

Ha: $b_{3} \neq 0$,

Variabel Tingkat Akreditasi $\left(\mathrm{X}_{3}\right)$ berpengaruh terhadap Kualitas Lulusan (Y)

Statistik uji menggunakan statistik t, dimana hasil t-hitung dari tabel 8diatas, diperoleh t-hitung $=2,062$, dengan nilai signifikansi 0,043 atau $4,3 \%$. Jika ditetapkan nilai probabilitas kesalahan uji dalam penelitian sebesar $5 \%(\alpha=5 \%=0,05)$, maka hasil uji menyatakan koefisien regresi variabel Tingkat Akreditasi $\left(b_{3}\right)$ signifikans. Yang Menyatakan Tingkat Akreditasi berpengaruh signifikans terhadap Kualitas Lulusan.

\section{Nilai Korelasi dan Determinasi}

Selanjutnya, juga untuk menguatkan hasil pengolahan data dalam meyakini pengambilan kesimpulan penelitian, dilakukan perhitungan nilai korelasi dan determinasi dari hubungan dan kontribusi variabel yang di duga dalam penelitian ini yakni Anggaran Pendidikan $\left(\mathrm{X}_{1}\right)$, Kualitas Pendidik $\left(\mathrm{X}_{2}\right)$, dan Tingkat Akreditasi $\left(\mathrm{X}_{3}\right)$, terhadap Kualitas lulusan (Y) SMA di Provinsi Aceh, maka di tinjau nilai korelasi dan determinasinya.

\section{Nilai Koefisien Korelasi dan Dterminasi}

Hasil olahan data untuk menentukan nilai korelasi secara bersama-sama anara variabel Anggaran Pendidikan $\left(\mathrm{X}_{1}\right)$, Kualitas Pendidik $\left(\mathrm{X}_{2}\right)$, dan Tingkat Akreditasi $\left(\mathrm{X}_{3}\right)$, terhadap Kualitas lulusan $(\mathrm{Y})$, diperoleh dengan rumus korelasi Pearson berikut:

Hasil perhitungan, diperoleh:

(1) Korelasi secara simultan antara variabel Anggaran Pendidikan $\left(\mathrm{X}_{1}\right)$, Kualitas Pendidik $\left(\mathrm{X}_{2}\right)$, dan Tingkat Akreditasi $\left(\mathrm{X}_{3}\right)$, terhadap Kualitas lulusan $(\mathrm{Y})$ adalah $\mathrm{R}=0,507$.

\begin{tabular}{|c|c|c|c|}
\hline $\mathrm{R}$ & R Square & Adjusted R Square & Std. Error of the Estimate \\
\hline $.507^{\mathrm{a}}$ & .258 & .223 & 3.05457 \\
\hline
\end{tabular}

Maka terdapat hubungan yang positif antara ketiga variabel yang diduga dalampenelitian terhadap variabel kualitas lulusan, dengan derajat sedang. Dan Nilai Determinasi adalah $R^{2}=0,258$ artinya kontribusi dari faktor Anggaran Pendidikan $\left(\mathrm{X}_{1}\right)$, Kualitas Pendidik $\left(\mathrm{X}_{2}\right)$, dan Tingkat Akreditasi $\left(\mathrm{X}_{3}\right)$, terhadap Kualitas lulusan (Y) adalah sebesar 25,8\%. Terdapat cukup besar faktor lainnya yakni 74,2\%.

Korelasi secara parsial masing-masing variabel Anggaran Pendidikan $\left(\mathrm{X}_{1}\right)$, Kualitas Pendidik $\left(\mathrm{X}_{2}\right)$, dan Tingkat Akreditasi $\left(\mathrm{X}_{3}\right)$, terhadap Kualitas lulusan $(\mathrm{Y})$ adalah :

Tabel 9. Korelasi antar Variabel

\begin{tabular}{|l|l|r|}
\hline \multirow{3}{*}{ Anggaran Pendidikan } & & Kualitas Lulusan \\
\cline { 2 - 3 } & Pearson Correlation & -.229 \\
\cline { 2 - 3 } & Sig. (2-tailed) & .059 \\
\cline { 2 - 3 } Kualitas Pendidik & Pearson Correlation & 69 \\
\cline { 2 - 3 } & Sig. (2-tailed) & $.443^{* *}$ \\
\cline { 2 - 3 } & $\mathrm{N}$ & .000 \\
\hline Tingkat Akreditasi & Pearson Correlation & 69 \\
\cline { 2 - 3 } & Sig. (2-tailed) & $.351^{* * *}$ \\
\cline { 2 - 3 } & $\mathrm{N}$ & .003 \\
\hline
\end{tabular}

Dari tabel diatas, maka korelasi antara Anggaran pendidikan sangat kecil dan berharga minus 0,229. Korelasi Kualitas Pendidik cukup besar yakni 0,443 dan bernilai positif terhadap Kualitas Lulusan. Serta Korelasi antara Tingkat Areditasi memiliki kategori sedang yakni 0,351 terhadap Kualitas Lulusan.

\section{c. Pembahasan}

Sebagaimana tujuan penelitian yang hendak dicapai, yakni membuktikan ada tidaknya pengaruh variabelvariabel yang diduga yakni Anggaran Pendidikan $\left(\mathrm{X}_{1}\right)$, Kualitas Pendidik $\left(\mathrm{X}_{2}\right)$, dan Tingkat Akreditasi $\left(\mathrm{X}_{3}\right)$, terhadap Kualitas lulusan (Y) SMA di Provinsi Aceh. Dan hasil penelitian dengan pendekatan analisis 
model regresi berganda (Multiple Regression) membenarkan bahwa terdapat hubungan yang signifikan ketiga variabel bebas (Anggaran Pendidikan, Kualitas Pendidik, dan Tingkat Akreditasi sekolah) terhadap variabel terikat (Kualitas lulusan) pada kasus data tahun 2017-2019, dengan alat statistik uji-F, dan diperkuat dengan nilai koefsisien korelasi sebesar 0,507.

Namun secara parsial perlu dirinci dengan penjelasan dalam pembahasan berikut ini.

\section{Pengaruh Anggaran Pendidikan terhadap Kualitas Lulusan Siswa SMA}

Sebagaimana diungkapkan dalam konsep dan ukuran tentang operasional variabel bahwa anggaran pendidikan suatu wilayah, dalam data Neraca Pendidkan Daerah oleh Kemendikbud, selain dengan meninjau kebutuhan dana untuk pendidikan, juga dana pembangunan infrastruktur. Dari 2 (dua) dimensi ini, maka indikator pengukurnya dalam memperoleh data anggaran pendidikan adalah 1). Kebutuhan dana utk kualitas pendidikan, 2). Pembangunan infrastruktur, 3). Sarana dan prasarana pendidikan, dan 4). Dana peningkatan kompetensi guru.

Dalam penelitian yang dilakukan pada data tahun 2017-2019 di Provinsi Aceh, ternyata variabel anggaran pendidikan tidak berpengaruh terhadap kualitas lulusan siswa SMA, sebagaimana dinyatakan dalam uji-t yang dideskripsikan ukurannya pada tabel 8 terdahulu. Berdasarkan hasil uji-t, secara statistik dengan taraf uji 5\% bahwa anggaran pendidikan tidak berpengaruh terhadap kulaitas lulusan siswa SMA di provinsi Aceh tahun 2017-2019.

Hasil ini bertolak belakang dengan hasil penelitian dari Manoto Togatoro (2017), tentang "Pengaruh Biaya Pendidikan terhadap Mutu Sekolah SMA Swasta di Kabupaten Tangerang", dimana hasil yang diperoleh bahwa terdapat pengaruh yang positif antara variabel biaya pendidikan terhadap mutu sekolah SMA Swasta di Kabupaten Tangerang.

\section{Pengaruh Kualitas Pendidik terhadap Kualitas Lulusan Siswa SMA}

Konsep dan ukuran yang digunakan dalam penelitian ini mengenai kualitas pendidik adalah tingkat kemampuan atau kecerdasan guru yang dinilai melalui kompetensi pedagogik, profesional, kepribadian dan sosial, nilai ini menurut ukuran yang dihitung dalam data Neraca Pendidkan Daerah Kemendikbud, adalah Nilai Uji Kompetensi Guru (NUKG) masing-masing kabupaten/kota di Provinsi Aceh pada setiap tahun, yang dihitung dalam satuan tingkat pencapaian Uji Kompetensi tersebut. Dimana terdapat 4 (empat) kompetensi yang menjadi indikator pengukurnya, yaitu kompetensi akademik, kompetesi pedagogik, kompetensi sosial, dan kompetensi profesi guru. Rata-rata kualitas pendidik atas dasar hasil Ujian Kompetensi guru SMA di Provinsi Aceh masih rendah dari nasional, dimana tahun 2017 baru mencapai 45,75 dari target nasional 70. Dan tahun 2019, UKG guru SMA di Provinsi Aceh baru mencapai 51,05 dari target nasional 80. Pada tahun tersebut yang paling unggul di Aceh adalah Kota langsa, mencapai 57,54 sedangkan yang paling renadah adalah Kabupaten Pidie Jaya dengan nilai UKG 45,22.

Dalam penelitian yang dilakukan pada data tahun 2017-2019 di Provinsi Aceh, variabel kualitas pendidik sangat berpengaruh secara signifikans terhadap kualitas lulusan siswa SMA, sebagaimana dinyatakan dalam uji-t yang dideskripsikan dengan nilai statistik uji $\mathrm{t}=2,885$ yang signifikans pada level uji atau kekeliruan hanya $0,5 \%$. Sehingga dapat dipastikan kualitas pendidik berpengaruh secara signifikans terhadap kualitas lulusan siswa SMA di Provinsi Aceh.

Hasil ini sejalan dengan logika kita bahwa, dengan memiliki guru yang berkompetensi akan mampu menghasilkan peserta didik yang berkualitas. Dan ini terbukti bahwa kualitas pendidik menentukan kualtas lulusan. Hal ini di dukung dari hasil penelitian, seperti Asep Priatna (2011), yang Berudul Pengaruh Profesionalitas Guru terhadap Kualitas Pembelajaran pada SMA di Kota Bandung, dimana hasilnya dinyatakan bahwa peningkatan kompetensi kualifikasi guru dan sertifikasi dimaksudkan untuk mendorong organisasi pembelajaran, dedikasi, loyalitas dan profesionalitas guru, yang diharapkan akan berpengaruh positif pada kinerja dan prestasi kerjanya pada era globalisasi ini. Prestasi kerja tersebut akan terlihat dari kualitas lulusan satuan pendidikan sebagai SDM yang berkualitas, produktif dan kompetitif. Dalam menghadapi era globalisasi yang penuh dengan persaingan dan ketidakpastian, dibutuhkan guru visioner dan mampu mengelola proses belajar mengajar secara efektif dan inovatif. Persaingan yang makin ketat serta tingkat kepercayaan masyarakat terhadap kualitas sekolah menjadi daya pendorong untuk terus menerus meningkatkan kompetensi guru. Upaya mencapai visi dan misi yang mengamanatkan kualitas peserta didik. Disamping identifikasi tataran nyata yang dihadapi sekolah dalam mencapai mutu yang diharapkan menjadi referensi pentingnya kompetensi guru. Dari hasil penelitian di SMA Kota bandung, diperoleh bukti bahwa taraf signifikansi antara variabel Profesionalitas Guru dan Kualitas Pembelajaran berdasarkan hasil perhitungan berada pada kategori kuat. Koefisien diterminasi (KP) diperoleh sebesar 
61,10\%. Artinya variabel Kualitas Pembelajaran dipengaruhi oleh variabel Profesionalitas Guru sebesar $61,10 \%$ sedangkan $38,90 \%$ dipengaruhi oleh faktor lain.

Dalam artikel Hardian Mursito (16 Juni 2016, https://www.kompasiana.com) tentang "Profesionalisme Guru sebagai Indikator Keberhasilan dalam Peningkatan Prestasi Belajar Siswa", disebutkan bahwa dalam upaya meningkatkan mutu pendidikan, aspek utama yang ditentukan adalah kualitas guru. Sukes tidaknya para peserta didik dalam belajar di sekolah, salah satu nya tergantung pada pendidik. Mengingat keberadaan pendidik dalam proses kegiatan belajar mengajar sangat berpengaruh, maka sudah semestinya kualitas pendidik harus diperhatikan dan ditingkatkan. Salah satu usaha yang dapat dilakukan melalui kualifikasi pendidikan guru sesuai dengan persyaratan minimal yang ditentukan syarat-syarat guru profesional. Berdasarkan hasil penelitian yang dilakukan Hardian (2016), dapat ditarik kesimpulan bahwa Profesionalisme guru adalah salah satu Indikator keberhasilan peningkatan prestasi belajar siswa di SMK PGRI I Jakarta.

\section{Pengaruh Tingkat Akreditasi Sekolah terhadap Kualitas Lulusan SMA}

Konsep dan ukuran yang digunakan dalam penelitian ini mengenai variabel Akreditasi Sekolah adalah tingkat pencapaian Akrediditasi rata-rata SMA di suatu wilayah (Kabupaten/Kota) di Provinsi Aceh pada tahun pengamatan, yaitu proses penilaian secara komprehensif terhadap kelayakan satuan atau program pendidikan, yang hasilnya diwujudkan dalam bentuk pengakuan dan peringkat kelayakan dalam bentuk yang diterbitkan oleh suatu lembaga yang mandiri dan profesional. Yaitu Badan Akreditasi Nasional. Penentuan Tingkat Akreditasi, didasarkan perbandingan yang capai semua SMA di Suatu Daerah yang dihitung, dibandingkan dengan Akreditasi idealnya (A).

Dalam penelitian yang dilakukan pada data tahun 2017-2019 di Provinsi Aceh, variabel tingkat Akrediditasi Sekolah berpengaruh secara signifikans terhadap kualitas lulusan siswa SMA, sebagaimana dinyatakan dalam uji-t yang dideskripsikan dengan nilai statistik uji $t=2,062$ yang signifikans pada level uji atau kekeliruan 4,3\%. Sehingga dapat dipastikan tingkat Akrediditasi Sekolah berpengaruh secara signifikans terhadap kualitas lulusan siswa SMA di Provinsi Aceh.

Hasil ini sejalan dengan penelitian dari Puput Novita Indriyawati, Muazza, dan Kuswanto, dengan judul "Pengaruh Akreditasi Sekolah terhadap Kualitas Lulusan SMA Se Kota Jambi Tahun 2017”, diperoleh bahwa dengan Sampel penelitian ini sebanyak 22 SMA Negeri dan Swasta se Kota Jambi pada tahun 2017, menggunakan teknik sampling purvosive, menunjukkan bahwaterdapat pengaruh signifikan antara Akreditas terhadap kualitas lulusan SMA Se Kota Jambi Tahun 2017.

Juga penelitian dari Sururi (2016) menghasilkan bahwa; Perolehan akredtasi tersebut dilihat dari Kurikulum dan Pembenaran, Administrasi dan Manajemen Sekolah, Organisai dan Kelembagaan Sekolah. Sarana dan Prasarana. Ketenagaan, Pembiayaan dan Pendanaan, Peserta didik, Peran Serta Masyarakat, Lingkungan dan Budaya Sekolah. Akreditasi sekolah dapat memberikan kontribusi yang positif terhadap peningkatan mutu pendidkan di Sekolah Menengah Kejuruan se- Kota Bandung. Hal dapat diartikan bahwa apabila akreditasi sekolah berjalan dengan baik, maka peningkatan mutu pendidikan berdampak baik pula.

\section{Simpulan (Conclusions}

Berdasarkan hasil dan pembahasan masalah penelitian ini, dapat ditarik beberapa simpulan dan temuan, sebagai berikut:

1. Hasil pengujian ditemukan bahwa faktor Anggaran Pendidikan tidak berpengaruh terhadap Kualitas lulusan SMA di Provinsi Aceh. Sedangkan faktir Kualitas Pendidik (dengan indikator hasil UKG Guru), dan Tingkat Akreditasi Sekolah (dengan indikator perhitungan tingkat kualitas akreditasi setiap Kabupaten di Provinsi Aceh) selama tahun 2017-2019, berpengaruh signifikans terhadap Kualitas Lulusan SMA di Provinsi Aceh.

2. Nilai korelasi secara simultan antara variabel Anggaran Pendidikan, Kualitas Pendidik, dan Tingkat Akreditasi, terhadap Kualitas lulusan (Y) adalah sebesar $\mathrm{R}=0,507$. Maka terdapat hubungan yang positif antara ketiga variabel yang diduga dalam penelitian terhadap variabel kualitas lulusan, dengan derajat sedang. Dan Nilai Determinasi adalah $\mathrm{R}^{2}=0,258$ artinya kontribusi dari faktor Anggaran Pendidikan $\left(\mathrm{X}_{1}\right)$, Kualitas Pendidik $\left(\mathrm{X}_{2}\right)$, dan Tingkat Akreditasi $\left(\mathrm{X}_{3}\right)$, terhadap Kualitas lulusan $(\mathrm{Y})$ adalah sebesar $25,8 \%$. Terdapat cukup besar faktor lainnya yakni 74,2 \%.

3. Korelasi secara parsial masing-masing variabel yakni korelasi antara Anggaran pendidikan sangat kecil dan berharga minus 0,229 terhadap kualitas lulusan. Sedangkan Korelasi Kualitas Pendidik cukup besar 
yakni 0,443 dan bernilai positif terhadap Kualitas Lulusan. Serta Korelasi antara Tingkat Areditasi memiliki kategori sedang yakni 0,351 terhadap Kualitas Lulusan.

\section{DAFTAR PUSTAKA (References)}

1) Abdulloh, Ridwan Sani. 2015. Pembelajaran Saintifik untuk Implementasi Kurikulum 2013. Jakarta: Bumi Aksara

2) Amri, Sofan, 2013. Peningkatan Mutu Pendidikan Sekolah Dasar dan Menengah. Prestasi Pustaka: Jakarta.

3) Asep Priatna. 2011, yang Berudul Pengaruh Profesionalitas Guru terhadap Kualitas Pembelajaran pada SMA di Kota Bandung, Jurnal Administrasi Pendidikan, Vol 14 Nomor Tahun 2011, online di https://ejournal.upi.edu/index.php/ JAPSPs/article/view/6415

4) Bungin, Burhan, 2001. Metode Penelitian Sosial. Surabaya: Airlangga University Press.

5) Dedi Supriadi. 2004, Satuan Biaya Pendidikan Dasar dan Menengah, Bandung: PT Remaja Rosdakarya.

6) Ferdi W. P, 2013, Jurnal Pendidikan dan Kebudayaan Vol. 19 Nomor 4, Desember 2013

7) Hardian Mursito. 2016, Profesionalisme Guru sebagai Indikator Keberhasilan dalam Peningkatan Prestasi Belajar Siswa (Kasus di SMK PGRI I Jakarta) Hasil penelitian, di akses pada situs:, https://www.kompasiana.com, 16 Juni 2016.

8) Indiantono, M. A., \& Sutopo. 2013. Analisis Pengaruh Kualitas Pelayanan Onlne Reservation Ticket Terhadap Kepuasan Pelanggan (Studi Kasus pada PT Kereta Api Indonesia Daop 4 Semarang). (Doctoral dissertation, Fakultas Ekonomika dan Bisnis).

9) Indopos.co.id, 19 September 2018. Fokus Peningkatan Kualitas Pendidikan https://indopos.co.id/ $\mathrm{read} / 2018 / 09 / 19 / 150100 /$ fokus-peningkatan-kualitas-pendidikan.

10) Mulyono. 2010, Konsep Pembiayaan Pendidikan, Jogjakarta: Ar-Ruzz Media

11) Nurochim. 2016, Administrasi Pendidikan, Bekasi: Gramata Publishing

12) Nur Nasution. 2005, Manajemen Mutu Terpadu (Total Quality Management), Bogor: Ghalia Indonesia

13) REPUBLIKA.CO.ID, JAKARTA, Kamis 14 Mar 2013. Anggaran Pendidikan Belum Mampu Tingkatkan Kualitas Pendidikan, https://www.republika.co.id/berita/pendidikan/ eduaction/13/03/14/

14) Rohmah Ageng Mursita, 2015. Guru Merupakan Penentu Keberhasilan Pendidikan : Realitasnya Masih Banyak Sekolah kekurangan Guru, https://www.kompasiana.com/ beprocess123/55b8565c927a61c8134654da/guru.

15) Sabar Budi Raharjo, dkk, 2018, Capaian Standar Nasional Pendidikan Sebagai Prediktor Mutu Sekolah, Jurnal Pendidikan dan Kebudayaan, Vol. 3, Nomor 2, Desember 2018

16) Salsabila Rasdi, 2016. Anggaran Pendidikan Indonesia dalam Upaya Peningkatan Kualitas Indonesia, https://www.kompasiana.com/salsabila_rsd/573b0705f392736a0707d11f/ anggaran pendidikan ...

17) Sekaran, Uma. 2011. Research Methods for business Edisi I and 2. Jakarta: Salemba Empat.

18) Sri Minarti. 2011, Manajemen Sekolah, (Jogjakarta: Ar-Ruzz Media.

19) Singgih Santoso. 2009. Panduan lengkap menguasai statistika dengan spss17. Elex Media Komputindo:

20) Sururi. 2016, Pengaruh Akreditasi Sekolah terhadap Peningkatan mutu Pendidikan di SMK Se-Kota Bandung, diakses pada situs: https://media.neliti.com/media/publications/74511-ID

21) Sugiyono, 2011, Metode penelitian kuntitatif kualitatif dan $R \& D$. Alfabeta

22) Uhar Suharsaputra. 2010, Administrasi Pendidikan, (Bandung: PT Refika Aditama.

23) Uwes Sanusi, 1991. Manajemen Pengembangan Mutu Dosen. Jakarta: Logos Wacana Ilmu

24) Umaidi. 1999, Sebuah Pendekatan Baru Dalam. Pengelolaan Sekolah Untuk Pening ... Pendidikan Berbasis Mutu, Jakarta : Pustaka Pelajar

25) Puput Novita Indriyawati, Muazza, , dan Kuswanto. 2017, Pengaruh Akreditasi Sekolah terhadap Kualitas Lulusan SMA Se Kota Jambi Tahun 2017, Hasil Penelitian, Universitas Jambi. 